\title{
Assessment of Herpes Simplex Virus Type 1 and 2 by IHC in Association with CD14 Antigen in Placental Tissues from Women with Miscarriage
}

\author{
Zainab A. Hamid \\ Department of Microbiology \\ Baghdad Medical College \\ University of Baghdad \\ Baghdad, Iraq. \\ zainabhamid96@gmail.com
}

\author{
Solaf J. Ali \\ Department of Community Health \\ Technical College of Health \\ Sulaimani Polytechnic University \\ Sulaimani, Iraq \\ solaf.jawhar@spu.edu.iq
}

\author{
Ali Hattem Hussain \\ Department of Community Health \\ Technical College of Health \\ Sulaimani Polytechnic University \\ Sulaimani, Iraq \\ ali.hussain@spu.edu.iq
}

\begin{abstract}
Among many viral causes of miscarriage, maternal infections caused by herpes simplex virus type -1 (HSV-1) and Herpes simplex virus type-2 (HSV-2) infections are important causes. CD14 was implicated in immune mechanisms, and might be involved in pregnancy loss. The aim of this study was to detect the possible occurrence of two $\mathrm{HSV}-1$ and $\mathrm{HSV}-2$ infections as well as the immunological factor cd14 in placental tissues from patients with spontaneous abortion using immunohistochemistry techniques. Immunohistochemistry technique assay was used to detect placental infection with $\mathrm{HSV}-1 \& \mathrm{HSV}-2$ as well as CD14 in 40 women with spontaneous miscarriage and in 40 healthy deliveries in Baghdad/Iraq. The IHC- expressions of $\mathrm{HSV}-1, \mathrm{HSV}-2$, and $\mathrm{CD} 14$ proteins were detected in 4(10\%), 15(37.5\%), 15(37.5\%) in placental tissues from miscarriage women, respectively. The association between CD14 with $\mathrm{HSV}-1$ and $\mathrm{HSV}-2$ among the placental tissues from miscarriage patients was constituting (5\%), (20\%) with $\mathrm{HSV}-1$ \& $\mathrm{HSV}-2$, respectively. The considerable proportion of $H S V-1, H S V-2$, and infections found in the placental tissues from miscarriage women could drag the attention of obstetricians to implicate these viruses as possible targets in the etiology of spontaneous abortion case and there is possible association of CD14 with $\mathrm{HSV}-1$ and $\mathrm{HSV}-2$ in women with abortion.
\end{abstract}

Keywords: Herpes viruses, Immunohistochemistry, Miscarriage, Pregnancy, Placenta, CD14.

\section{INTRODUCTION}

The causes of abortions in many cases are still unknown [1]. However microbial Infections represent a major cause in abortion, of which viruses appear to be the most frequently involved pathogens [2]. Among many viruses, Human Herpes virus infections of placenta may be harmful in pregnancy leading to disorders in fetal growth, premature delivery, miscarriage, or major congenital abnormalities [3], and some of them can produce chronic or recurrent maternal infection. In particular, CMV during pregnancy can reach the placenta by viremia. Herpes simplex virus type 2 and less frequently type 1 cause recurrent infections of the genital tract and can lead to abortion [4]. Among many possible causes of abortions, immunological factors might be attributed to abortion, yet these factors have not been clearly elucidated. The CD14, CD 56, CD100, CD72, CD45, and HLA-G implicated in immune mechanisms and are involved in pregnancy loss [5].

The aim of this study was to investigate the differences in the occurrence of two herpetic viral infections in placental tissues from patients with spontaneous abortion through determination of infections with HSV-1, and HSV-2 involving the placenta as a possible causes for subsequent abortion as well as to have an insight in a panel of the immunological factor CD14 shared in the placental microenvironment in an attempt to find a close relationships of this markers to the state of abortions by using immunohistochemistry technique.

\section{METHODS AND MATERIALS}

This retrospective study made the use of paraffin embedded placental tissues which were collected from histopathological archives of Teaching Laboratories at AL-Yarmouk Teaching Hospital /Iraq and belonging to (40) female patients with miscarriage as patients group, their ages were ranged between 19 to 43 years, and 40 placental tissues of normal delivery as a control group. Expose Mouse and Rabbit Specific HRP IDAB Detection IHC Kit ab80436 (2013) Abcam was used for detection of HSV-1, HSV-2 and CD14 protein specific primary antibodies. Statistical analysis of data was carried out using the available statistical package of SPSS-22 (Statistical Packages for Social Sciencesversion 22).

\section{RESULTS}

The IHC- expressions of the proteins of any of the tested markers were detected as a brownish discoloration or signal at nuclear or cytoplasmic localizations. The HSV1 protein was detected in 4 out of $40(10 \%)$ placental tissues from miscarriage women, Herpes simplex virus type- 2 antigen was noticed in 15 out of $40(37.5 \%)$ of IHC reactions in the miscarriage placental tissues group. The score results of CD14 - IHC reaction in miscarriage 
placental tissues group show that $(37.5 \%)$ were positive for this marker while the control group has showed $7.5 \%$ of the examined placental tissues. It was noticed that $57.5 \%$ (23 out of 40 ) of placental tissues of miscarriage group showed negative reactions for both HSV-1(IHC) and $\mathrm{CD} 14$ (IHC) where as a percentage of 5\%(2 out of 40) of placental tissues have positive-IHC reactions of both CD14 molecule and HSV-1 protein . In the control placental tissues, positive results for both HSV-2 and CD14 was $2.5 \%$ ( 1 out of 40 ) cases where as $92.5 \%$ were negative for both these markers. (Table 4, Figure 1). Statistically The association of the HSV-1 and CD14, showed no significant differences among miscarriage group ( $>>0.05)$, while significant differences was found among health control group $(\mathrm{p}<0.05)$.
It was noticed that $45 \%$ (18 out of 40 ) of placental tissues of miscarriage group showed negative reactions for both HSV-2(IHC) and CD14(IHC) whereas $20 \%(8$ out of 40) of placental tissues have positive-IHC reactions of both CD14 molecule and HSV-2 protein. In the control placental tissues, positive results for both HSV-2 and CD14 was $5 \%(2$ out of 40 ) cases where as $90 \%$ were negative for both these markers. (Table 5, Figure 4-26). Statistically The association of the HSV-2 and CD14, showed no significant differences among miscarriage group $(\mathrm{p}>0.05)$, while significant differences was found among health control group $(\mathrm{p}<0.05)$.

Table (1): Immunohistochemical signal scoring \& signal intensity results of HSV-1 detection in tissues from miscarriage and successfully delivered women.

\begin{tabular}{|c|c|c|c|c|c|c|}
\hline $\begin{array}{l}\text { HSV-1 IHC signal Score \& } \\
\text { Signal intensity }\end{array}$ & & $\begin{array}{l}\text { Miscarriage } \\
\text { Group }\end{array}$ & & $\begin{array}{l}\text { Control } \\
\text { Group }\end{array}$ & & $\mathrm{P}$ value \\
\hline \multirow{6}{*}{ HSV-1IHC Positive Score } & & No & $\%$ & No & $\%$ & \\
\hline & Negative & 36 & 90.0 & 38 & 95.0 & 0.396 \\
\hline & Positive & 4 & 10.0 & 2 & 5.0 & \\
\hline & Score I & - & - & 2 & 100 & - \\
\hline & Score II & 1 & 25.0 & - & - & \\
\hline & Score III & 3 & 75.0 & - & - & \\
\hline \multirow{3}{*}{$\begin{array}{l}\text { HSV-1IHC } \\
\text { Intensity }\end{array}$} & weak / I & - & - & 1 & 50.0 & \\
\hline & Moderate / II & 4 & 100 & 1 & 50.0 & \\
\hline & strong / III & - & - & - & - & \\
\hline
\end{tabular}

Table (2): Frequencies distribution of immunohistochemical reaction results of HSV-2 protein according to their signal scoring and signal intensity.

\begin{tabular}{|c|c|c|c|c|c|c|c|}
\hline \multicolumn{3}{|c|}{$\begin{array}{l}\text { HSV-2 IHC signal Score \& } \\
\text { Signal intensity }\end{array}$} & \multicolumn{2}{|c|}{$\begin{array}{l}\text { Miscarriage } \\
\text { Group }\end{array}$} & \multicolumn{2}{|c|}{$\begin{array}{l}\text { Control } \\
\text { Group }\end{array}$} & \multirow[t]{2}{*}{$\mathrm{P}$ value } \\
\hline \multirow{6}{*}{$\begin{array}{l}\text { HSV-2IHC } \\
\text { Score }\end{array}$} & \multirow{6}{*}{ Positive } & & No & $\%$ & No & $\%$ & \\
\hline & & Negative & 25 & 62.5 & 37 & 92.0 & $0.001 *$ \\
\hline & & Positive & 15 & 10.0 & 2 & 5.0 & \\
\hline & & Score I & 3 & 20 & 3 & 100 & - \\
\hline & & Score II & 6 & 40.0 & - & - & \\
\hline & & Score III & 6 & 40.0 & - & - & \\
\hline \multirow{3}{*}{$\begin{array}{l}\text { HSV-2IHC } \\
\text { Intensity }\end{array}$} & \multirow[t]{3}{*}{ Positive } & weak / I & 3 & 20.0 & 1 & 66.7 & 0.252 \\
\hline & & Moderate / II & 11 & 73.3 & 1 & 33.3 & \\
\hline & & strong / III & 1 & 6.7 & - & - & \\
\hline
\end{tabular}

Table (3): Stratification of signal scoring and signal intensity of immunohistochemical reactions for detection of CD14 protein in the studied groups.

\begin{tabular}{|c|c|c|c|c|c|c|}
\hline \multicolumn{2}{|l|}{$\begin{array}{l}\text { CD14 IHC signal Score \& } \\
\text { Signal intensity }\end{array}$} & \multicolumn{2}{|c|}{$\begin{array}{l}\text { Miscarriage } \\
\text { Group }\end{array}$} & \multicolumn{2}{|c|}{$\begin{array}{l}\text { Control } \\
\text { Group }\end{array}$} & \multirow[t]{2}{*}{$\mathrm{P}$ value } \\
\hline \multirow{6}{*}{ CD14IHC Positive Score } & & No & $\%$ & No & $\%$ & \\
\hline & Negative & 25 & 62.5 & 37 & 92.0 & $0.0001 *$ \\
\hline & Positive & 15 & 37.5 & 3 & 7.5 & \\
\hline & Score I & 9 & 60.0 & 2 & 100 & - \\
\hline & Score II & 1 & 6.7 & - & - & \\
\hline & Score III & 6 & 40.0 & - & - & \\
\hline \multirow{3}{*}{$\begin{array}{l}\text { CD14IHC } \\
\text { Intensity }\end{array}$} & weak / I & 3 & 20.0 & 2 & 66.7 & 0.217 \\
\hline & Moderate / II & 7 & 46.7 & 1 & 33.3 & \\
\hline & strong / III & 5 & 33.3 & - & - & \\
\hline
\end{tabular}


Table (4): Association between HSV-1 and CD14 in the studied placental tissues.

\begin{tabular}{|c|c|c|c|c|c|c|}
\hline \multirow[t]{3}{*}{ CD14 IHC Score } & \multicolumn{3}{|c|}{ Miscarriage Group } & \multicolumn{3}{|l|}{ Control Group } \\
\hline & \multicolumn{3}{|c|}{ HSV-1 IHC Score } & \multicolumn{3}{|c|}{ HSV-1 IHC Score } \\
\hline & Negative & Positive & Total & Negative & Positive & Total \\
\hline Negative & $23(57.5 \%)$ & $\begin{array}{c}2 \\
(5 \%)\end{array}$ & $25(62.5 \%)$ & $36(90 . \%)$ & $1(2.5 \%)$ & $37(92.5 \%)$ \\
\hline Positive & $13(32.5 \%)$ & $2(5 \%)$ & $15(37.5 \%)$ & $2(5 \%)$ & $1(2.5 \%)$ & $3(7.5 \%)$ \\
\hline Total & $36(90 \%)$ & $4(10 \%)$ & $40(100 \%)$ & $38(95 \%)$ & $2(5 \%)$ & $40(100 \%)$ \\
\hline $\mathrm{P}$ value 0.586 & & 0.019 & & & & \\
\hline
\end{tabular}

Table (5): The Association between HSV-2 and CD14 in the studied placental tissues.

\begin{tabular}{|c|c|c|c|c|c|c|}
\hline \multirow[t]{3}{*}{ CD14 IHC Score } & \multicolumn{3}{|c|}{ Miscarriage Group } & \multicolumn{3}{|l|}{ Control Group } \\
\hline & \multicolumn{3}{|c|}{ HSV-2 IHC Score } & \multicolumn{3}{|c|}{ HSV-2 IHC Score } \\
\hline & Negative & Positive & Total & Negative & Positive & Total \\
\hline Negative & $18(45 \%)$ & $7(17.5 \%)$ & $25(62.5 \%)$ & $36(90 . \%)$ & $1(2.5 \%)$ & $37(92.5 \%)$ \\
\hline Positive & $7(17.5 \%)$ & $8(20 \%)$ & $15(37.5 \%)$ & $1(2.5 \%)$ & $2(5 \%)$ & $3(7.5 \%)$ \\
\hline Total & $25(62.5 \%)$ & $15(37.5 \%)$ & $40(100 \%)$ & $37(92.5 \%)$ & $3(7.5 \%)$ & $40(100 \%)$ \\
\hline \multicolumn{7}{|l|}{$\mathrm{P}$ value 0.109} \\
\hline
\end{tabular}

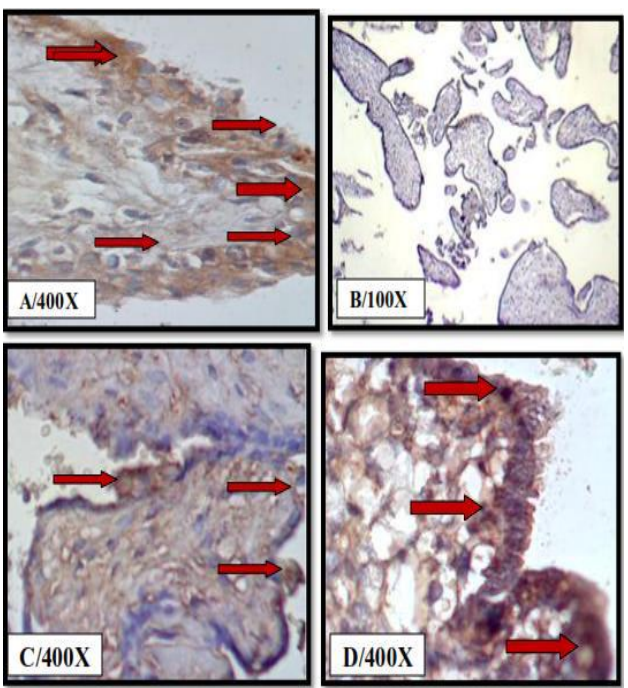

Figure 1: Microphotograph of IHC staining of trophoblastic placental tissues from miscarriage patients (red arrow): A-HSV1 in cell cytoplasm showed score 3 and moderate intensity. B- Negative IHC-signal staining for HSV1. C- HSV2 in cell cytoplasm showed score 2 and strong intensity. D- IHC staining for CD14 within the inflammatory cells of trophoblastic placental tissues showed score 3 and strong intensity.

\section{DISCUSSION}

Infection with herpes simplex is common in women of reproductive age. It can be contracted and transmitted to the fetus during pregnancy and the newborn [6]. Extra villous trophoblast cells express HSV entry mediators and are susceptible to infection by HSV-1, which may result in impaired placental invasion and miscarriage [7]. The infrequency with which congenital HSV-1 infection occurs may be attributed to several factors, these factors: the prevalence in reproductive-aged women of protective antibodies against HSV1, and the possibility that the placenta functions to preventing vertical transmission of HSV from the maternal to the fetal circulation as a physical barrier. Our results are a bit higher than another earlier study done by Sifakis, and associates (1998), who examined women with spontaneous abortion by PCR and serological assays and found HSV1/2 genome in 3 cases $(2.9 \%)$, out of total cases [8].

HSV-1 well known to infect both orofacial areas, yet in some developed countries herpes simplex virus type 1 has yet emerged as the prominent causative agent in genital lesions. Changes in sexual behaviors of young adults may partly explain its incidence in the genital tract [9]. Our results disagree with earlier reports regarding this subject here in a study done by Robb and coworker (1986) who examined 200 cases of spontaneous abortion for detection of HSV antigen [10]. They found that placental HSV positivity (39\% positive) was significantly correlated with spontaneous abortion.

Villous trophoblast cells were found resistant to infection by HSV-1 and may serve as a barrier that prevents vertical transmission of $\mathrm{HSV}-1$ although these villous syncytiotrophoblast is in direct contact with 
maternal blood and forms a continuous layer between the maternal and fetal circulation [7]. However, in a previous study done by Hideki Koi, et.al, they found that primary maternal infections with $\mathrm{HSV}-1$ were common during pregnancy and associated with an increased risk of miscarriage e, perhaps as a result of placental dysfunction.

Among the placental tissues (40) in the miscarriage group, only 15 cases (37.5\%) showed positive HSV-2 IHC reactions. Statistically, the overall HSV-2 -IHC scoring of miscarriage placental tissues on comparing to their tissues control showed significant differences $(\mathrm{p}<0.001)$. Our study showed a significant correlation between HSV infection and the studied cases of abortions

According to our findings, HSV-1 infections may be acquired before the pregnancy, therefore, it is associated with low risk of occurrence of spontaneous abortions. Our results are consistent to these done by Syridou et al [11], where by using nested PCR they found 6\% (1/18) of specimens in SA group were HSV1/2 positive, while in consistent to our result since they did not detect HSV infection in their control group.

Similar results were found in study done by Matia et.al, in Iran using PCR, were they found that $2.8 \%(1 / 35)$ of samples taken from aborted materials were HSV positive [12].

More recently in a study done to investigate the prevalence of herpes simplex virus-1/2 infection by molecular and serological techniques in women with spontaneous miscarriage in the first trimester of pregnancy has found HSV-1/2 DNA using real-time quantitative polymerase chain reaction (Real-time qPCR), and serological assays that (7) out of the $(1,716)$ specimens were positive for HSV-1/2 DNA and by serology, $39.7 \%$ for HSV IgG, The lack of virus DNA in the majority of cases indicates that HSV-1/2 infection is not commonly associated with spontaneous abortion[13].

Since HSV-2 infection is ubiquitous, the risk of fetal transmission gave this virus the importance as a global public health issue, particularly because HSV-2 infection is most common among women of childbearing age. The primary infection with HSV-2 has been inconclusively linked with abortions [14].

The present results are consistent with Kapranos and Kotronios results, where they proposed a significant role for HSV2 in the first trimester- related pregnancy losses (as detected by the sensitive and accurate nested- PCR). Here in, these researchers detected HSV-2 (43.2\%) in those with early pregnancy losses and among them (16.7\%) of cases could be related to those cases with elective pregnancy termination [15]. This might be explained in that herpetic viral reactivation could frequently occurs during the first months of pregnancy which frequently be related to the effects of progesterone-linked immuno-depression.

On comparison, the present results were higher than the results of other study done on a total of 210 serum samples from women in Baghdad with history of abortions who were screened for the presence IgM and $\mathrm{IgG}$ antibodies in their sera against Herpes simplex virus type 2, using (ELISA) and they found that (4.76\%) of these sera were positive for HSV2 $\operatorname{IgM}$ antibodies in the group of recurrent spontaneous abortion cases [16].
This and present results could be explained in that these infectious agents may induce a shift of immune response during pregnancy from $\mathrm{Th} 2$ to $\mathrm{Th} 1$ and consequently lead to a rejection as an abortion process and the presented results are supported by the results of Makhseed, et.al.[17].

The present results were higher in comparison to a study done in Brazil (by using polymerase chain reaction (PCR) and has showed a percentage of $(9.0 \%)$ of HSV-2 in the maternal-side placental tissues (decidua) samples, whereas only seven cases (3.5\%) were positive for HSV2 on the fetal side [18], which in turn might reflect a great deal of variations of infection rates within the regions or geographical variations within the individual immune status.

Our results disagree with a study done by Eskild et al, who examined 281 women with fetal deaths after the 16th weeks of gestation and 961 controls of live born children to assess the relations of fetal deaths with an infection of herpes simplex virus type-2. They found no evidence of an association between HSV-2 infection during pregnancy and fetal deaths using serological assays [19].

The present results got their importance and also supported by the results of EI Kalu et.al, who had found that first episode of HSV-2 infection among pregnant women in Benin, Nigeria were associated with an increased risk of spontaneous abortion occurrence [20]. The CD 14 surface antigen is expressed on monocytes as co-receptor for detection of bacterial lipopolysaccharide, and as such this function makes CD14 as one of innate immune system [21].

The current study detects of CD14 in the miscarriage placental tissues group (37.5\%) than CD14 antigen expression in control placental tissues group (7.5\%). Significant differences $(\mathrm{p}<0.05$ ) were found between placental tissue in the miscarriage and control groups.

The obtained results are in agreement with the findings of a study done by Quenby, et al, where he found that there was an elevated expression in CD4+, CD14+, CD16+, CD56+and MHC class II+ cellular surface markers in tissues obtained from placental women with recurrent miscarriage. However, there are few reports about the role of CD14 during miscarriage cases [22].

The explanations for the higher rates of CD14 expression in the current results might be related to the presence of mild inflammation in miscarriage pregnancy which might result in activation of monocytes due to inflammatory response to low levels of fetal antigens derived from fetal tissues or placenta. This inflammation is mediated by innate immune mechanisms of which active monocyte (increased intracellular reactive oxygen species, and expression of surface CD14, CD11b, and CD64 receptors) are one of them, and as observed and stated by JE LIM, et al [23].

Thus, this study has revealed an increase in the expression of CD14 which is among many possible mechanisms which might be associated with miscarriage. Two possibilities can explain the increment in CD 14 expression: first one is that abortion will lead to inflammation and this will increase CD14+ monocytes whereas the second is that due to the immunological process these $\mathrm{CD} 14+$ monocytes will mediate the 
secretion of cytokines like TNF and others which are in turn would have role and then lead to the abortion.

This finding did not rule out the possibility that endotoxin might also be an etiologic factor in spontaneous miscarriage. The possibility that endotoxin might be another etiologic factor in increase CD $14+$ monocytes as a possible immune mechanism against bacterial infection. Regarding the expression of the immunological markers in relation to the HSV-1 infection, and although the current study revealed no statistical significant relationships between CD14 protein expression and such viral infections there are still slightly evidence of correlation. The results of CD14 could be related to escape of HSV-1 from host immune system, and although macrophages play a vital role in controlling Herpes simplex virus type-1, the herpes simplex virus type 1 that was detected in our series of patient is one of the viruses that cause persistent infection which possess genes that encode ligands for inhibitory receptors that mainly expressed on macrophage cells in order to escape from host immune system. HSV-1 infection caused most macrophage cells to cluster as well as to be attached to each other. In addition, HSV-1 infection changed the expression levels of CD14 [24], the results of current study revealed that collectively, herpes simplex virus use an inhibitory immune receptor to enter and invasion into the cells and that is beneficial to the virus because binding to inhibitory receptors may provide entry. Regarding the expression of the CD14 in relation to the HSV2 infection the results suggested that there is a considerable role for CD14 in association with HSV-2 in the studied groups since it has been detected in both miscarriage and healthy control study groups., although there has been a lack of association between HSV-2 and CD14 since J.

Arii et.al, denoted that HSV-2 was not able to infect primary human CD14-positive - mononuclear cells [25], which predominantly consist of monocytes or macrophages, the results presented herein are in accordance with Ellermann who claimed a possibility for different susceptibilities of these cells to the HSV-2. During infection of HSV-2 macrophages are activated and increased antiviral potential, the macrophage antiviral activity has either intrinsic or extrinsic effects [26]. The extrinsic antiviral activity refers to the ability of macrophages to inactivate virus outside the macrophage or to inhibit viral replication in other cells. The intrinsic antiviral activity depends on other factors on macrophage differentiation and has been correlated to IFN activity. In conclusion the highest percentage of HSV2 infections in patients might indicate for an important contribution of such virus in the etiologic development of miscarriage among patients group. Although HSV-1 infection was not found commonly, yet such HSV-1 infection rates should be considered critically at this time, since this virus has recently emerged as a prominent causative agent in genital lesions. The increased expression of CD14 marker in the miscarriage patients could indicate either an inflammatory influx of CD14 associated with results from abortion or an immunological process via CD $14+$ monocytes which mediate the secretion of cytokines like TNF and others that in turn would have role leading to these abortions.

\section{CONCLUSION}

The considerable proportion of HSV-1, HSV-2, and infections found in the placental tissues from miscarriage women could drag the attention of obstetricians to implicate these viruses as possible targets in the etiology of spontaneous abortion case and there is possible association of CD14 with HSV-1 and HSV-2 in women with abortion.

\section{REFERENCE}

[1] A Oliver, C Overton, "Diagnosis and management of miscarriage" Practitioner, 258 (3), PP. 25-28, 2014.

[2] ZR Khameneh, H Hanifian, R Barzegari, N Sepehrvand, "Human parvovirus B19 in Iranian pregnant women: a serologic survey, Indian Journal of Pathology and Microbiology, 57 (3), pp. 442444, 2014.

[3] Di Stefano M, Calabrò ML, Di Gangi IM, Cantatore S, Barbierato M, "In Vitro and In Vivo Human Herpesvirus 8 Infection of Placenta," PLOS ONE, 3 (12), e4073, 2008

[4] A Festary, V Kourí, C Correa, V Denis, "Cytomegalovirus and Herpes Simplex Infections in Mothers and Newborns in a Havana Maternity Hospital," International journal of Cuba health \& medicine, 17 (1), PP. 29-34, 2015.

[5] CD Truong, W Feng, Li W, "Characteristics of Epstein-Barr virus-associated gastric cancer: a study of 235 cases at a comprehensive cancer center in U.S," Journal of Experimental and Clinical Cancer Research, 28 (1):14-21, 2009

[6] G Straface, A Selmin, V Zanardo, M De Santis, A Ercoli, G Scambia, " Herpes Simplex Virus Infection in Pregnancy," Infectious Diseases in Obstetrics and Gynecology, 27 (1), PP. 287-293, 2012.

[7] K Hideki, Z Jian Zhang, A Makrigiannakis, S Getsios, C MacCalman, J Strauss, S Parry, "Syncytiotrophoblast Is a Barrier to Maternal-Fetal Transmission of Herpes Simplex Virus," Biology of Reproduction, 67 (5), pp. 1572-1579, 2002.

[8] S Sifakis S, E Koumantakis , M Koffa, M Ergazaki , DA Spandidos, "Detection of herpes simplex virus (HSV) in aborted material using the polymerase chain reaction technique," Gynecologic and Obstetric Investigation, 45 (2), pp. 109-115, 1998.

[9] R Gupta, T Warren, A Wald, "Genital herpes," The Lancet, 370 (9605), pp. 2127-2137, 2007.

[10] JA Robb, K Benirschke, R Barmeyer, "Intrauterine latent herpes simplex virus infection: I. Spontaneous abortion," Human Pathology, 17 (12), pp. 1196-209, 1986.

[11] G Syridou, N Spanakis, A Konstantinidou, ET Piperaki, D Kafetzis, E Patsouris, "Detection of cytomegalovirus, parvovirus B19 and herpes simplex viruses in cases of intrauterine fetal death: association with pathological findings," Journal of Medical Virology, 80 (10):1776-1782, 2008.

[12] S Matia, S Masoud, 1 Chamani, R Bagheri, K Kamali, "PCR Detection of Herpes Simplex Virus in Human Placenta and Aborted Materials in Patients with Spontaneous Abortion," Archives of Clinical Infectious Diseases, 6 (2), pp.17-20, 2008.

[13] S Zhang, T Regnault, P Barker, K Botting, I McMillen, C McMillan, C Roberts, JL Morrison, "Placental Adaptations in Growth Restriction, Nutrients, 7 (1), PP. 360-389, 2015.

[14] F Fabiana, O Lisiane, R Gisele, "Herpes Simplex Virus: Prevalence in Placental Tissue and Incidence in Neonatal Cord Blood Samples," Journal of Medical Virology, 6 (1), PP. 75-81, 2013.

[15] NC Kapranos , DC Kotronias, " Detection of herpes simplex virus in first trimester pregnancy loss using molecular techniques," In Vivo, 23 (5), PP. 839-842, 2009.

[16] J Gutiérrez, F Fernández, MJ Vergara, S Suárez, MJ Soto, MC Maroto, " Comparison of several ELISA tests for detecting the presence of $\operatorname{IgG}$ and $\operatorname{IgM}$ against herpes simplex viruses," Microbios, 103(405), PP. 127-32, 2000.

[17] M Makhseed, R Raghupathy, F Azizieh, A Omu, E Al-Shamali , L Ashkanani ," Th1 and Th2 cytokine profiles in recurrent aborters with successful pregnancy and with subsequent abortions," Human Reproduction, 16 (10), pp. 2219-2226, 2001. 
[18] LM Weiss, YY Chen, "EBER in situ hybridization for EpsteinBarr virus," .Methods in Molecular Biology, 999 (2), pp. 223$230,2013$.

[19] A Eskild, S Jeansson, B Stray-Pedersen, P Jenum, " Herpes simplex virus type- 2 infection in pregnancy: no risk of fetal death: results from a nested case-control study within 35,940 women," Obstetrics and Gynecology, 109 (9), pp. 1030-1035, 2003.

[20] E Kalu, C Ojide, A Chuku, I Chukwuonye, F Agwu, V Nwadike, F Korie, G Okafor, " Obstetric outcomes of human herpes virus-2 infection among pregnant women in Benin, Nigeria," Nigerian Journal of Clinical Practice, 18(4):453-461, 2015.

[21] D Ranoa, S Kelley, R Tapping, " Human lipopolysaccharidebinding protein (LBP) and CD14 independently deliver triacylated lipoproteins to Toll-like receptor 1 (TLR1) and TLR2 and enhance formation of the ternary signaling complex," Journal of Biology Chemistry, 288 (14), pp. 9729-41, 2013.

[22] S Quenby, M Bates, T Doig, J Brewster, Lewis-DI Jones, PM Johnson, G Vince, "Preimplantation endometrial leukocytes in women with recurrent miscarriage," Human Reproduction, 14(9):2386-2391, 1999.

[23] JE Lim, T Kim, NW Lee, MJ Oh, HJ Seol, JY Min, HJ Kim, " CD14 receptor gene promoter polymorphism: awakening maternal immunity during pregnancy," Journal of International Medical Research, 34 (2):176-82, 2006.

[24] A Reichard, N Cheemarla, N Bigley,"SOCS1/3 Expression Levels in HSV-1-Infected, Cytokine-Polarized and -Unpolarized Macrophages," Journal of Interferon \& Cytokine Research, 35 (1), PP. 32-41, 2015.

[25] J Arii, M Uema, T Morimoto, "Entry of Herpes Simplex Virus 1 and Other Alphaherpesviruses via the Paired ImmunoglobulinLike Type 2 Receptor $\alpha$," Journal of Virology, 83 (9):4520-4527, 2009.

[26] S Ellermann-Eriksen, "Macrophages and cytokines in the early defence against herpes simplex virus," Virology Journal, 2 (1), PP. 59-64, 2005. 